\title{
Role of Employee Pro-activeness in the Repatriation Process: A Study of Indian IT Industry
}

\author{
Muniza Aftab ${ }^{1}$, Mohammad Israrul Haque ${ }^{2}$ and Tanuja Sharma ${ }^{3}$ \\ ${ }^{1}$ Research Scholar, ${ }^{2}$ Professor, ${ }^{1 \& 2}$ Department of Business Administration, Aligarh Muslim University, Uttar Pradesh, India \\ ${ }^{3}$ Professor, Management Development Institute (MDI), Gurgaon , Haryana , India \\ E-mail: Muniza_Aftab@yahoo.co.in
}

\begin{abstract}
Repatriation experience is attributed to many factors, a phenomenon much lesser studied compared to expatriation. Considered as merely coming back home could be extremely stressful as given to understand through previous studies and while many factors could attribute to the same, many practitioners argued that it could be repatriate's own attitude towards pro-activeness that is an increasingly important component of the repatriate transition outcome. The study includes the feedback of such repatriates from the IT companies and understands the behaviour they were involved in while returning back home. It further establishes the role of proactiveness and provides a set of suggestions for repatriates returning home.

Keywords: Repatriate, Repatriation, proactive behaviour, International mobility, I.T. Industry
\end{abstract}

\section{INTRODUCTION}

With increased International mobility and globalization, the organizations witnessed an evolution in finding markets outside the home country resulting in global careers for its employees. This started the trend of expatriation of employees and got the focus of all the organizations, however, repatriation of the same employees back home did not capture the attention as it was considered merely coming back home.

Repatriation is defined as "the process of return to the home country at the completion of an international assignment (Narayanan \& Dyer, 1990). However, Repatriation is a multi-layered phenomenon, affecting almost all roles of life; individuals and corporations have a synchronizing effect on repatriation outcome.

Many studies have been done to understand the factors that lead to successful repatriation. It has been discussed that repatriates who perceive more organizational support, coworker support will better adjust to their repatriation transition.

Individual variables such as age, length of overseas stay, and personality may also influence repatriation adjustment (Valk et al. 2015).

However, an individual's own ability and sense of urgency to make things better may have a role to play too. This study tries to understand if an employee's pro-active behaviour has any impact on his repatriation experience.

Repatriate re-adjustment can be considered as a process of reducing the possibility of uncertainty which may be anticipated (Adler, 1981; Black et al., 1992; Harvey, 1989). The reduction of ambiguity or increasing certainty may happen by becoming more informed and act as per guideline and rules (Tyler, 1982). The anticipatory factors would reduce the uncertainty and facilitate the repatriate adjustment whereas the factors which increase uncertainty will be having a reverse impact of the relationship. As per , Black et al, 1992 "there is all the proof that that adjustment of an expatriate would consist of (1) adjustment to the work, (2) adjustment to interacting with local residents, and (3) adjustment to the overall non-work environment”.

Understanding Proactive behaviour: The other important concept which this study tries to understand is proactive behaviour at work and how it leads to making things happen. It involves self-initiated action, such that the employee is more aware of the situation or oneself and in better command of things.

The examples can be varied and are not just limited to taking charge, but leading the change by improving work methods and proactive problem-solving. Whilst this personalized approach is valid, we prefer to focus on proactive actions within a particular context, recognizing that proactive behaviour is shaped not only by one's overarching personality, but by one's motivation in a particular context (Uta K. Bindl and Sharon, 2010).

Crant (2000) defines proactive behaviour as taking initiative in improving the current situation or creating new ones; it also means challenging the current status and taking ownership in working towards improving the same rather than passively adapting to present conditions.

Leiba O'Sullivan (2002) suggests that "Big Five personality characteristics: extraversion, conscientiousness, openness to experience, emotional stability, or agreeableness influence on repatriation transition outcomes through repatriates' protean behaviour". 
Also, it's been concluded by Jassawala and Sashittal, 2009 that the optimistic repatriates adjust the environment and easily advance in their career. As per Crant (2000), one of the important components of job performance is that managers should be more proactive on the job.

He further describes four constructs related to proactive behaviour: proactive personality, personal initiative, role breadth self-efficacy, and taking charge and also suggests that proactive behaviour is a complex, multiply-caused phenomenon that has important personal and organizational consequences.

There are certain ways that an employee may be showing pro-active behaviour while repatriation for e.g. contacting others to get information about specific positions, contacting with his network on housing and schooling back home, Updating self to ensure that he is aware on changes back home on return and contacting HR/repatriate officer for future assignments. As it appears these behaviours have in common an emphasis on taking control of a situation by looking ahead and initiating change.

These behaviours are partially determined by the disposition and partially influenced by situational forces.

The networking behaviours would mean that an employee is attempting to develop and maintain relationships with others who have the potential to assist work or career, So those attempting to make successful repatriation make contacts to develop a network and make themselves aware and become prepared for that may come on the way (O' Sullivan,2008).

In the context of job adjustment and creativeness, the job changers' studied coping strategies in terms of seeking information from others, understanding changing work procedures, and working long hours (Feldman \& Tompson, 1993). He found that these proactive strategies have a significant influence on various aspects of the general satisfaction at the job.

For example, looking for the positive side of the job positively influences general satisfaction and intention to remain; changing procedure and working long hours positively influences satisfaction with growth opportunity.

This study supports the effectiveness of proactive behaviours for better adjustment, the generalizability of this finding to the repatriation. "'Similarly, Leiba O'Sullivan(2002) suggests repatriation behaviour such as social networking and information-seeking aimed at securing repatriation support is an alternative means to manage repatriation transition, and self-initiation behaviour is needed in both stages before and after the repatriation. The model suggests proactive personality characteristics that lead to proactive behaviours which are the predictors of successful repatriation outcomes.

\section{METHODOLOGY}

The study tries to understand the repatriation of employees in the IT industry where the Onshore and offshore model is in place. At onshore which is typically a client location, hundreds of employees are deployed with a team offshore, which can be any branch in India.

An International assignment in an IT Company may last up to 2-5 years where the returning employees after the end of the assignment are called repatriates and the process of the same is called Repatriation. The focus of the study is this employee and the pro-activeness which he may or not exhibit in this process and the research objective is to understand the impact of employee pro-activeness on repatriate readjustment experience.

\section{A. Research Instrument and Sampling}

The tool of the study is a questionnaire. The quantitative research methods were used and the questionnaire was sent through email or in-person through the hard copy to IT repatriates.

The Snowball sampling method was used and this questionnaire was applicable to those who have returned from the overseas assignments of at least 6 months and have returned not more than 3 years back.

The sample size of this study was 202 and these respondents were asked questions to measure their attempt on showing proactive behaviour on a scale of 1 (lower side) to 5 (higher side). He was asked on his attempt of contacting others to get information about specific positions, He making proactive measures on understanding any housing and schooling back issues, keeping updated of self on any changes back home, and proactively connecting with HR or repatriate officer for any assistance proactively.

\section{B. Profile of Respondents}

A total of 202 repatriates working in IT/ITES companies participated in the survey (Table I). Descriptive Statistics reveal that the respondents were predominantly male (72.3\%). More than $50 \%$ of respondents are in the Age group of 28-35 years with $60 \%$ engineering graduates. The majority of respondents were Married (73.5\%) but without children at the time of deputation. The statistics divulge about $50 \%$ of respondents had work experience of 10-15 years followed by $5-10$ years of experience (27.7\%). $80 \%$ had returned within the last 2 years and $70.8 \%$ had returned as per the initial plan/expectations. Also, the Sample Description also shows that more than $80 \%$ of the respondents were from Indian IT giants - TCS, Infosys, Wipro, and HCL, and the remaining from the other relatively medium IT firms. 
TABLE I SAMPLE DESCRIPTION

\begin{tabular}{|c|c|c|}
\hline Age & Frequency & Percentage \\
\hline 22-27 Years & 16 & 7.9 \\
\hline 28-35 Years & 113 & 55.9 \\
\hline 36-42 Years & 57 & 28.2 \\
\hline 43-50 Years & 13 & 6.4 \\
\hline Above 50 Years & 3 & 1.5 \\
\hline Gender & Frequency & Percentage \\
\hline Male & 146 & 72.3 \\
\hline Female & 56 & 27.7 \\
\hline Highest Education level & Frequency & Percentage \\
\hline BE/B.Tech & 125 & 61.9 \\
\hline Graduation other than engineering & 16 & 7.9 \\
\hline Post Graduation-MCA/M.Tech & 38 & 18.8 \\
\hline Post Graduation - MBA/PGDBM & 23 & 11.4 \\
\hline Marital Status & Frequency & Percentage \\
\hline Single & 53 & 26.2 \\
\hline Married & 149 & 73.8 \\
\hline Experience & Frequency & Percentage \\
\hline $0-5 \mathrm{yrs}$ & 17 & 8.4 \\
\hline $5-10$ yrs & 56 & 27.7 \\
\hline $10-15$ yrs & 102 & 50.5 \\
\hline $15-20$ yrs & 21 & 10.4 \\
\hline Above 20 yrs & 6 & 3.0 \\
\hline Return type & Frequency & Percentage \\
\hline Pre-mature & 59 & 29.2 \\
\hline As expected & 143 & 70.8 \\
\hline Time since return from overseas & Frequency & Percentage \\
\hline less than 6 months & 45 & 22.3 \\
\hline 6-12 months & 45 & 22.3 \\
\hline 12-24 months & 71 & 35.1 \\
\hline 24-36 months & 41 & 20.3 \\
\hline
\end{tabular}

\section{IIi RESULTS AND DISCUSSION}

As discussed above, the employee pro-active behaviour at work is his go get attitude and self-initiating behaviour The following table measures the impact of employee pro-activeness on the experience of his repatriation. and anticipating the struggles beforehand and keeping an attitude to take responsibility on self to solve them.

\section{TABLE II IMPACT OF EMPLOYEE PRO-ACTIVENESS ON HIS EXPERIENCE OF REPATRIATION (RESULTS OF SEM IN TABULAR FORM)}

\begin{tabular}{|c|c|c|c|c|}
\hline Independent Variable & Dependent Variable & Estimate & $\mathbf{P}$ & Result \\
\hline Employee Pro-activeness & Employee experience of repatriation & .188 & .015 & Positive and Significant \\
\hline
\end{tabular}

The results show that employee pro-activeness has a positive impact (estimate value at 0.188) which is statistically significant with $\mathrm{P}$-value at $.015(\mathrm{P}<0.05)$ on Repatriate Readjustment Experience. This clearly indicates that the proactiveness of the repatriate will have a significantly positive impact on his experience of repatriation. Demographic factors like Gender, Age, Marital status, experience and time since return were tested in detail to see the result on pro-activeness of employees 
TABLE III T-TEST RESULTS BASED ON GENDER

\begin{tabular}{|c|c|c|c|c|c|c|c|}
\hline Variable & Gender & N & Mean & $\begin{array}{c}\text { Std } \\
\text { Deviation }\end{array}$ & T Value & Sig. & Result \\
\hline \multirow{2}{*}{ Employee Pro-activeness } & Male & 146 & 2.6370 & .78459 & .025 & .980 & \multirow{2}{*}{ No Significant difference } \\
\cline { 2 - 8 } & Female & 56 & 2.6339 & .74310 & & & \\
\hline
\end{tabular}

The results of the ANOVA T-test signify that there is no significant role of Gender on Employee proactiveness. The Sig. value is $>0.05$ which supports that there is no significant difference observed and any distinction on the pro-activeness exhibited by the employee is not dependent if it's a male or female employee.
Another important demographic influencer can be the 'Age' of the repatriate in determining his proactive behaviour.

TABLE IV T-TEST RESULTS BASED ON AGE

\begin{tabular}{|c|c|c|c|c|c|c|c|}
\hline Variable & Age & $\mathbf{N}$ & Mean & Std Deviation & F Value & Sig. & Result \\
\hline \multirow{5}{*}{ Employee Pro-activeness } & $22-27$ yrs & 16 & 2.7969 & .94083 & \multirow{5}{*}{.322} & \multirow{5}{*}{.863} & \multirow{5}{*}{$\begin{array}{c}\text { No Significant } \\
\text { difference }\end{array}$} \\
\hline & $28-35$ yrs & 113 & 2.6350 & .71732 & & & \\
\hline & $36-42$ yrs & 57 & 2.6009 & .78185 & & & \\
\hline & $43-50$ yrs & 13 & 2.6731 & .86834 & & & \\
\hline & Abv 50 yrs & 3 & 2.3333 & 1.52753 & & & \\
\hline
\end{tabular}

The results of the ANOVA T-test signify that there is no significant role of Age on Employee pro- activeness. The Sig. value is $>0.05$ which supports that there is no significant difference observed and any distinction on the pro-activeness exhibited by the employee is not dependent if he is young or old.
The role of 'Marital Status' was tested. As it was assumed that married employee may take any self-initiated efforts while repatriating

TABLE V T-TEST RESULTS BASED ON MARITAL STATUS

\begin{tabular}{|c|c|c|c|c|c|c|c|}
\hline Variable & Marital Status & $\mathbf{N}$ & Mean & Std Deviation & T Value & Sig. & Result \\
\hline \multirow{2}{*}{ Employee Pro-activeness } & Single & 53 & 2.6651 & .71546 & \multirow{2}{*}{.317} & \multirow{2}{*}{.751} & \multirow{2}{*}{$\begin{array}{c}\text { No Significan } \\
\text { difference }\end{array}$} \\
\hline & Married & 149 & 2.6258 & .79250 & & & \\
\hline
\end{tabular}

The results of the ANOVA T-test signify that there is no significant impact of Marital Status on Employee proactiveness. The Sig. value is $>0.05$ which supports that there is no significant difference observed and any distinction on the pro-activeness exhibited by the employee is not dependent if he is Married or Single.
The Total experience of the employee is an indicator of his maturity and can impact his sel- initiated behaviour. Based on this assumption $\mathrm{T}$ Test was conducted on total employee experience.

TABLE VI T-TEST RESULTS BASED ON TOTAL EXPERIENCE

\begin{tabular}{|l|c|c|c|c|c|c|c|}
\hline \multicolumn{1}{|c|}{ Variable } & Total Experience & $\mathbf{N}$ & Mean & Std Deviation & F Value & Sig. & Result \\
\hline \multirow{3}{*}{$\begin{array}{l}\text { Employee Pro- } \\
\text { activeness }\end{array}$} & $0-5$ yrs & 17 & 2.7794 & .91379 & & & No Significant difference \\
\cline { 2 - 6 } & $5-10$ yrs & 56 & 2.6652 & .73589 & & \\
& $10-15$ yrs & 102 & 2.6127 & .75422 & \multirow{4}{*}{.885} & \\
\cline { 2 - 6 } & $15-20$ yrs & 21 & 2.7024 & .72292 & & \\
\cline { 2 - 6 } & Above 20 yrs & 6 & 2.1250 & 1.13743 & & & \\
\hline
\end{tabular}

The results of the ANOVA T-test signify that there is no significant impact of Total Employee experience on Employee pro-activeness. The Sig. value is $>0.05$ which supports that there is no significant difference observed and any distinction on the pro-activeness exhibited by the employee is not dependent if he is senior or junior in the organization. Another important aspect is the employee's time since return on his proactive behaviour. 
TABLE VII T-TEST RESULTS BASED ON TIME SPENT SINCE RETURN

\begin{tabular}{|c|c|c|c|c|c|c|c|}
\hline Variable & $\begin{array}{c}\text { Time spent since } \\
\text { return }\end{array}$ & $\mathbf{N}$ & Mean & Std Deviation & F Value & Sig. & Result \\
\hline \multirow{4}{*}{ Employee Proactiveness } & $<6$ Months & 45 & 2.7389 & 81351 & \multirow{4}{*}{2.165} & \multirow{4}{*}{.093} & \multirow{4}{*}{$\begin{array}{c}\text { No Significant } \\
\text { difference }\end{array}$} \\
\hline & 6-12Months & 45 & 2.5500 & .67756 & & & \\
\hline & 12-24 Months & 71 & 2.7535 & .82212 & & & \\
\hline & 24-36 Months & 41 & 2.4146 & .69284 & & & \\
\hline
\end{tabular}

The results of the ANOVA T-test signify that there is no significant impact of 'time since return' on Employee proactiveness. The Sig. value is $>0.05$ which supports that there is no significant difference observed and any distinction on the pro-activeness exhibited by the employee is not dependent on time since he has return.

\section{CONCLUSION}

The study considered that the employee protean behaviour or employee pro-activeness as one of the important factors impacting the repatriation experience which is found to be relevant to the repatriate readjustment experience in the previous studies. The results of this study also reveal the same and confirm that repatriates who engage in protean repatriation behaviours should have more successful repatriation transition outcomes than those who do not (Adler and Bartholomew, 1992). This study is in context of large IT companies establishes that the attitude and selfinitiating behaviour of the repatriates help them get better roles, timely elevation, and smoother experience on return.

This is in alignment with the results given by the study of O' Sullivan (2008) and James (2019) who suggested that those who exhibit proactive behaviours are in a better chance of successful repatriation. The above results also reciprocate the same in the Indian context that the proactive behaviour of the repatriate has a positive and significant impact on his repatriate readjustment experience. To conclude those who self -initiate and proactively contact their networks on their issues like housing, schooling, constantly update self to ensure that they are aware of changes back home and also reach out themselves to relevant stakeholders, have a strong positive impact on the repatriation results and hence the pro-active attitude to handling return transitions is measured as one of the major coping factors. Hence, this study suggests that while organizations might be establishing and process and policies in the area the repatriates must highly engage in proactive attitude and behaviour to better adjust to their repatriation transition. They must keep their old networks intact, keep informed on changes and proactively keep visibility of roles back home.

\section{REFERENCES}

[1] Adler, N. (1981). Re-Entry: Managing Cross-Cultural Transitions. Group \& Organization Studies, 6(3), 341-356.

[2] Adler, N., \& Bartholomew, S. (1992). Managing globally competent people. Academy Of Management Perspectives, 6(3), 52-65.
[3] Black, J., Gregersen, H., \& Mendenhall, M. (1992). Toward a Theoretical Framework of Repatriation Adjustment. Journal of International Business Studies, 23(4), 737-760.

[4] Crant, J. (2000). Proactive Behaviour in Organizations. Journal Of Management, 26(3), 435-462.

[5] Feldman, D., \& Tompson, H. (1993). Expatriation, Repatriation, and Domestic Geographical Relocation: An Empirical Investigation of Adjustment to new Job Assignments. Journal Of International Business Studies, 24(3), 507-529.

[6] Harvey, M. (1989). Repatriation of Corporate Executives: An Empirical Study. Journal of International Business Studies, 20(1), 131-144.

[7] James, R. (2019). Repatriates' Work Engagement: Proactive Behavior, Perceived Support, and Adjustment. Journal of Career Development, 089484531988610.

[8] Jassawalla, A., \& Sashittal, H. (2009). Thinking strategically about integrating repatriated managers in MNCs. Human Resource Management, 48(5), 769-792.

[9] Leiba O'Sullivan, S. (2002). The protean approach to managing repatriation transitions. International Journal of Manpower, 23(7), 597-616.

[10] Narayanan, S., \& Dyer, L. (1990). Book Reviews: International Dimensions of Human Resource Management by Peter J. Dowling and Randall S. Schuler (1990). PWS-Kent Publishing Co. Asia Pacific Journal Of Human Resources, 28(4), 134-135.

[11] O'Sullivan, E. (2008). Finding Our Way in the Great Work. Journal Of Transformative Education, 6(1), 27-32.

[12] Tyler, V. (1982). Cross-cultural encounters: Face-to-face interaction. International Journal Of Intercultural Relations, 6(4), 448-451.

[13] Uta K. Bindl and Sharon K ( 2010) proactive work behavior: forward-thinking and change-oriented action in organizations, Parker Institute of Work Psychology, University of Sheffield, United Kingdom

[14] Valk, R., Velde, M., Engen, M., \& Szkudlarek, B. (2015). Warm welcome or rude awakening?. Journal Of Indian Business Research, 7(3), 243-270. 